\title{
Criminalisation of migration for domestic work from Myanmar to Singapore-need for a radical policy shift
}

\section{Priya Deshingkar ${ }^{1}$}

Accepted: 21 December 2020 / Published online: 27 January 2021

(C) The Author(s) 2021

\begin{abstract}
Between 2014 and April 2019, the government of Myanmar banned international migration for domestic work to Singapore and criminalised the brokering of such migration as well as predeparture training and placement of migrants as domestic workers in Singapore. These measures were taken in response to concerns over the alleged abuse of migrant women as well as international pressures to eliminate trafficking and debt bondage. Experienced brokers and recruitment agencies who were trading openly up until then were forced to cease operations. At the same time, large numbers of inexperienced and uncouth recruitment agencies emerged to take advantage of the black economy created by the ban. This resulted in women migrating irregularly from Myanmar to Singapore being exposed to greater risks which the paper traces. Four discernible impacts of the ban on the recruitment practices and working conditions faced by migrant women from Myanmar before departure and after arriving in Singapore were identified: a sharp increase in migration and placement costs, inadequate predeparture training, placement in forced labour conditions with extended and unclear repayment periods and no access to support from the Myanmar government while in Singapore. Although the ban has since been lifted, the resulting migration system had placed workers in conditions of extreme exploitation with little recourse to justice or having their voices heard. The paper ends by summarizing the unanticipated negative consequences of the criminalisation of migration brokerage in Myanmar and lessons for other countries that may be considering controls on female migration.
\end{abstract}

Keywords Criminalisation $\cdot$ Human trafficking $\cdot$ Migration brokerage $\cdot$ Debt bondage $\cdot$ Forced labour

Priya Deshingkar

p.deshingkar@sussex.ac.uk

1 Department of Geography, University of Sussex, Brighton, UK 


\section{Introduction}

Between 2014 and April 2019, the government of Myanmar banned international migration for domestic work in response to widespread reports of abuse of Myanmar migrant female domestic workers, ${ }^{1}$ especially in Singapore (Wei 2015). Many experienced brokers in villages and towns and recruitment and placement agencies (RAs) ${ }^{2}$ based in cities were either imprisoned or forced to cease operations. Village or small town-based brokers and citybased RAs are the core of migration brokerage in Myanmar, and they rely on a variety of other actors such as passport officials and health certification centres that produce the required documentation for migrants. RAs would be responsible for training women in the skills required for domestic work before they placed them with employers. The ban resulted in the criminalisation of any activity related to the brokerage and placement of Myanmar women in Singapore and directly impacted on the activities of brokers and RAs such as advertising for domestic workers in Singapore and predeparture training. The ban was lifted in early 2019 as anecdotal evidence on continuing migration to Singapore and extreme exploitation was mounting. ${ }^{3}$ The Humanitarian Organization for Migrant Economics (HOME), an NGO working with migrant domestic workers in Singapore, estimates a doubling of the numbers of Myanmar female domestic workers (FDWs) in Singapore between 2013 and 2015 despite the ban being in place (Ma 2019).

In this paper, I discuss how the ban pushed an established and thriving industry of brokers and recruitment agencies underground and led to the emergence of a black market for migration brokerage and domestic worker placement which exacerbated exploitation and human suffering. There was no smuggling across borders involved in this kind of migration as most women travelled legally on tourist visas and were legally employed in Singapore, a process which I elaborate upon below. The paper draws on evidence gathered under a project on brokered migration ${ }^{4}$ between November 2017 and January 2019. The research aimed to understand the experiences of men and women who had migrated with the help of intermediaries to Singapore and Thailand. This paper is concerned with the findings from the Singapore part of the study which elicited the views of women who migrated during the ban as well as those who had migrated before the ban was introduced. Interviews were also conducted with recruitment and placement agencies that were in operation before the ban came into force. Further detail on the research methods is provided below.

The migration of Myanmar women to Singapore must be understood in the context of labour circulation in Southeast Asia, societal change in Singapore as well as structural factors related to poverty and gender norms in Myanmar. Migration patterns in the region indicate that migrants from relatively poor countries such as Myanmar, Indonesia and Philippines are channelled to high growth economies such as Singapore, Hong Kong and Malaysia to fill the gaps in reproductive labour that have arisen due to the shift of reproductive work from their

\footnotetext{
${ }^{1}$ The Asia and Pacific region hosts the largest share of domestic workers, with almost a quarter of the world's female migrant domestic workers (ILO 2017).

${ }^{2}$ I am calling them recruitment and placement agencies as they recruit women for domestic work that have been supplied by brokers and place them in Singapore homes.

${ }^{3}$ An estimated 50,000 women and girls migrated to Singapore between 2014 and 2019. Myanmar Times 26 April 2019

${ }^{4}$ British Academy and Department for International Development, UK Government funded project "Brokered Migration for Domestic Work and Construction Work in Ghana and Myanmar: Examining the Relevance of the Slavery and Trafficking Discourse"
} 
households to the market (Fong et al. 2020). Within Myanmar, structural and cultural constraints shape gendered patterns of migration with increasingly larger numbers of women looking for opportunities abroad. While Myanmar has made significant progress in improving tertiary education levels among women, most continue to be limited to poorly paid jobs in the informal sector due to cultural norms related to 'women's work' and how it should be valued (CEDAW 2016). With starting salaries in excess of SGD 450 (approximately USD 330) per month, domestic work in Singapore thus becomes an attractive option for women from Myanmar who would normally earn less than SGD 40 a month. Female migrants belonging to impoverished and indebted families or divorced women migrate in search of an income to support dependent children and build an independent life for themselves. San is one such woman who had decided to migrate at the age of 27 to provide for her natal family and children as her husband had left her and moved to Malaysia. In fact, Myanmar has now emerged as the leading labour exporting country in the Greater Mekong sub-region (IOM 2019). Although Singapore is the preferred destination for women from other Southeast Asian countries as well, Myanmar female labour migrants are being recruited in ever increasing numbers because they are not represented by strong advocacy organisations that will negotiate for higher wages and better working conditions on their behalf.

\section{A paternalistic state}

The emigration of women from Myanmar was officially permitted only in 2009 although it is clear that such migration had begun in practice long before then (ILO and UN Women 2017). Official programmes facilitating the migration of domestic workers began only in 2013, with pilots of domestic workers migrating to Hong Kong (China) and Singapore (Myanmar Times 2014 cited in ILO and UN Women 2017). Thus, the ban on migration for domestic work to Singapore occurred only a year after migration had been officially sanctioned. The ban was precipitated by concerns over the safety of female migrants after NGO and media reports drew attention to cases of abuse (Aljazeera 2 April 2018 From Myanmar to Singapore: why the maid trafficking continues).

The reasoning of the Myanmar government was simplistic: migrating women are unsuspecting victims of brokers and RAs who profit from the exploitation of migrants and profiteering is their main motive. The experience of other countries shows that such restrictions which victimise female migrants and impose bans on female-dominated migration streams are typically underpinned by gendered moralities and patriarchal anxieties related to their autonomy (Platt 2018; Awumbila et al. 2019). While there is no doubt that brokers employ tactics of deceit and cheating, the accounts given by women of the situation prevailing before the ban indicate a much more complex relationship between brokers and migrants.

Before the ban, there was a well-developed informal system of village-level brokers who were the main source of information for aspiring migrants. They were also responsible for setting fees and arranging travel documents and journeys. These brokers belonged to the same social background as the migrants, and the system of brokerage was based on long-established traditions of social reciprocity and obligation in the community. Take the case of San, who first migrated from rural Ayeyarwady in 2007 at the age of 27. She wanted to migrate to support her father who was struggling to provide for the family based on his erratic farming income. Her uncle put her in touch with a broker in Ma-Ubin town who was known to their relatives in the same town and carried the same ethnic identity of Bamar as San's family 
"Well, there was someone my uncle knew of and asked me if I'm interested in working abroad and I thought farming and livestock works here are quite tiresome and it would be nice over there and I was getting about 320 SGD back then" (roughly USD 235).

The broker's brother-in-law was working as a recruitment and placement agent in Yangon, and between the two of them, they promised to take care of all of San's needs including getting her passport made and fixing the terms of payment. Aspiring migrants like San and their families mobilised these relations of trust and co-ethnic bonds while negotiating the terms of migration. In a society where there was a mistrust of state agencies and official procedures, it was a completely natural choice for aspiring migrants to trust local brokers who came with recommendations of reliability from family and friends. The sentiment within the community was that experienced and known brokers would offer the migrant protection against a hostile, unknown world beyond their own lifeworld. Brokers are usually known and respected individuals in the community, and some were women who had worked as domestic workers in Singapore themselves and returned with important knowledge about travel, official regulations and required behaviours. Transactions between brokers and RAs and aspiring migrants and their families are bound by moral rules that both sides understand well. In the case of any cheating on a promise, these moral rules can be called upon. Similar processes were noted by Lindquist in his study of village-level brokerage in Indonesia (2012) and Deshingkar et al. (2019) in Bangladesh.

Under the ban however, processes of brokerage that were regarded as quite ordinary in everyday life were criminalised and a few highly experienced and well-respected brokers and recruitment agents were arrested. While these actors became illicit in the eyes of the state, they were much respected among aspiring and returned migrants who had migrated successfully through them. Sally, one of the women in our study, had decided to migrate after failing her 10th class exams. She belonged to a Christian family of six, and her father was a subsistence farmer. She herself had a low-level job in a government department, and she wished to migrate to improve the situation of the family. She recalls how all the women at the training centre that she attended in Yangon referred to the recruitment agent as 'teacher' and held her in esteem for giving them skills and assisting them in their migration project. Sally intended to give the agent something as a mark of respect on her return but discovered that the agent had been arrested. 'Before I came back here, I was thinking to pay some homage to her and I asked my friend about her and they told me that she was caught."

Thus, while the migrants themselves often described brokers and RAs as people who provided a service and helped them out of poverty, debt and joblessness, the state narrative characterised them as criminals who profited from the exploitation of migrants. Such conflicting narratives are by no means seen only in Myanmar, and I am guided by numerous ethnographic studies on migration brokerage which powerfully illustrate this split and the implications for the welfare of migrants. These include studies in West Africa (Awumbila et al. 2019), the Middle East (Osella 2014) and Southeast Asia (Lindquist 2012) among other places. These studies challenge simplistic stereotypes of brokers as criminals and migrants as victims to show how brokerage is culturally embedded and the relations between aspiring migrants and brokers. They also shed light on policy restrictions and criminalisation narratives that actually create the conditions for exploitation and unfree labour. Albeit showing a surprising level of commonality across different countries, these studies also document differences in the day-to-day practices of brokers, employers and state agencies in creating migrant precarity. 


\section{The criminalisation process in Myanmar}

The ban on migration for domestic work in Singapore was arguably the result of both a moralistic approach to the migration of women and also pressure from the international antitrafficking lobby. It happened at a time when a slew of policy measures had been taken to criminalise migrant brokerage in Myanmar in response to international pressure from the antitrafficking lobby. Myanmar passed the Anti-Trafficking in Persons Law in 2005, mirroring the 2000 UN Convention on Transnational Organized Crime which outlaws the movement of people for exploitation. ${ }^{5}$ Seen through the gaze of the state, the brokerage of women's migration to Singapore for the purposes of finding work as domestic workers is chiefly for profiteering rather than a service as viewed within the community. It has therefore become a punishable offence under the new rulings as has been the case in other countries in the Global South. ${ }^{6}$ Myanmar is now subject to assessment on its performance on eliminating trafficking by the US Government's Department of State Trafficking in Persons Report (TIP). Myanmar was downgraded to Tier 3 status in the 2018 TIP report because it did not "fully meet the minimum standards for the elimination of trafficking and is not making significant efforts to do so". Research from other countries has shown that anti-trafficking paradigms criminalise and stigmatise a broad array of migration intermediaries including village-level brokers (Alpes 2013; Spener 2009; Van Liempt and Sersli 2013).

\section{The Singaporean state: producing a precarious workforce}

Singapore has attracted considerable academic attention due to the its selective immigration regime which tightly regulates the residence of migrant workers while heavily limiting their rights (Wee et al. 2019; Chin 2019; Platt et al. 2017; Baey and Yeoh 2018). Migration for domestic work in Singapore shot up in the late 1990s after which the government brought in more restrictive policies. In order to reduce the demand for foreign workers, levies were introduced, and these are payable to the government at the time of recruitment. Foreign domestic workers are allocated to families based on stringent criteria related to their income and number of family members. According to Singapore regulations, domestic workers must be female, between 23 and 50 years of age, have at least eight years of formal certified education and come from an approved source country in Asia which includes Myanmar. Migrant workers are not permitted to become pregnant or deliver a child in Singapore. Passing a pregnancy test is required before entry and at six monthly medical examinations for STDs and other infectious diseases (ILO and UN Women 2017). Marriage is forbidden, and pregnancy or romantic liaisons can result in dismissal and repatriation of the worker. Furthermore, employers have to pay a security bond of $\$ 5000$ which they lose if the worker absconds. While entry and exit are controlled by the state, the regulation of wages and working conditions is left to the discretion of the employer which creates scope for exploitation and abuse (Parreñas et al. 2020). Live-in workers cannot separate work from their own leisure time

\footnotetext{
${ }^{5}$ The Palermo protocol defines human trafficking as "The recruitment, transportation, transfer, harbouring or receipt of persons, by means of the threat or use of force or other forms of coercion, of abduction, of fraud, of deception, of the abuse of power or of a position of vulnerability or of the giving or receiving of payments or benefits to achieve the consent of a person having control over another person, for the purpose of exploitation. Exploitation shall include, at a minimum, the exploitation of the prostitution of others or other forms of sexual exploitation, forced labour or services, slavery or practices similar to slavery, servitude or the removal of organs." ${ }^{6}$ See, for example, Okyere (2017) who discusses a similar process unfolding in Ghana.
} 
and are constantly on call, without fixed working hours or overtime payments (Fong and Yeoh 2020). As I show later in the paper, the accounts gathered during the course of this study indicate that levels of abuse increased during the ban.

Immigration in Singapore is under the purview of the Ministry of Manpower (MOM) which regulates temporary workers such as domestic workers. MOM has delegated the recruitment of domestic workers to private recruitment agencies (Goh et al. 2017) who work within the bounds of state regulations to ensure a steady and timely supply of a low paid and flexible workforce (Ma 2019). Since the ban came into force, working conditions of Myanmar FDWs have deteriorated as the recruitment and placement of Myanmar FDWs is being done by clandestine operators which results in inadequate predeparture training, higher recruitment fees as well as a lack of government support at destination if any problems arise. Other research has shown that the criminalisation of certain kinds of migration not only limits departures but actually creates the conditions for recruitment and placement into precarious and exploitative employment (Goldring et al. 2009; Provine and Doty 2011). The findings presented here prove this point in the Myanmar-Singapore context as well.

Despite the ban in Myanmar, Singapore continued to provide work permits to migrants as long as they complied with their requirements. What this meant in practice was that migrants who left their own country illegally were considered regular and documented in Singapore (MOLIP/UNWomen 2017; HOME 2019). Work permits seek to tie the worker to a particular employer, and foreign workers seeking employment in Singapore must take a MOM test to assess their competency for the job. Migrant workers are given instructions on how to contact MOM if they experience difficulties at work, but as I discuss later in the paper, they are rarely able to get such help.

\section{Methods}

The paper draws on evidence gathered through 15 months of research in Myanmar between November 2017 and January 2019, involving 40 semi-structured in-depth interviews of current and returned migrants working as domestic workers in Singapore. Additionally, a small number of interviews were conducted with village-level brokers and recruitment agencies in Yangon who were operating prior to the ban. Interviewees were selected on the basis of their willingness to participate and fulfilled the criteria of belonging to one of groups listed above. They were recruited through passive snowball sampling where the purpose of the research was explained to potential interviewees by their contacts and they were asked to indicate their interest prior to the research team contacting them. Snowball sampling has known drawbacks as it is a non-probabilistic method but was thought to be the best approach for identifying hard-to-reach interviewees on a topic that was politically sensitive. Rigorous ethics procedures were followed to ensure that consent, confidentiality, rights to withdraw and ask for data to be destroyed as well as anonymity were maintained. Interview guides were developed by the UK research team, ${ }^{7}$ and training was provided to the local researchers ${ }^{8}$ over 3 days on interviewing, recording, transcribing, observation and note taking. Each interview lasted between an hour and $90 \mathrm{~min}$ and was conducted at a time and place chosen by the respondent. The

\footnotetext{
${ }^{7}$ The author and Alex Ma, a PhD student at UCL.

${ }^{8}$ Names have been withheld to protect their identity.
} 
research was conducted in Yangon where most of the RAs are based and from where there is significant migration to Singapore. Some interviews were conducted by phone and Facebook Messenger with current migrants in Singapore identified through snowballing. Many of the migrants transiting through Yangon are originally from rural areas including Ayeyarwady, Kachin and Mandalay.

Interviews were also held with government officials and NGOs. Interviewing a range of actors provided a variety of perspectives and insights into the infrastructure of migration brokerage and how different components and levels of the system link up with each other. The interviews were conducted to understand the social relations that underpinned the brokering process at origin and the insertion of Myanmar female migrant domestic workers into Singaporean homes.

\section{Findings}

Networks of village or town-based brokers connect aspiring female migrants in remote rural areas to RAs in Yangon who work directly with placement agencies in Singapore to recruit, match and place migrant domestic workers in the homes of Singaporean employers. A majority of women in Myanmar as well as other Southeast Asian countries (Goh et al. 2017) are recruited through a model of debt migration which allows women from relatively poor backgrounds to migrate without having to finance the journeys and placement from their own pockets. The Myanmar RA sends the worker to Singapore on the understanding that the employer will pay the Myanmar broker and RAs costs which the employer then recovers through monthly deductions from the domestic worker. The length of deductions is agreed between the migrant and broker or RA before departure. Prior to the ban the total cost of migration was in the region of SGD 2000 and 2800 (roughly USD 1470 and 2060) with deductions lasting between 5 and 7 months during which time the worker received no pay, a pattern observed in the case of Indonesian migrant domestic workers in Singapore as well (Platt et al. 2013).

Aside from establishing a debt migration contract and facilitating the journey from rural Myanmar to Singapore, recruitment agencies also provide training to would-be domestic workers according to the expectations of Singapore employers with regard to competence in domestic duties, spoken English, dressing and behaviour. These expectations are conveyed to the Myanmar RA by the Singapore RA and Myanmar RAs tried to build up a reputation for supplying 'good' maids. Although aspiring migrants were aware of the possibility of being cheated by brokers and 'bad' employers in Singapore, on the whole they regarded brokers and recruitment agents as people who helped them.

Interviews with women who had migrated before the ban came into force indicated that recruitment agencies in Yangon offered a comprehensive programme of predeparture training to ensure that women from rural areas would know how to negotiate airport authorities and what to do on arrival in Singapore. They were given training in English and knowledge of kitchen management and care duties. Training would be between 3 and 6 months long depending on the qualifications of the applicant and their level of spoken English. This was confirmed by recruitment agents in the interviews we had with them. Blessings Recruitment Agency describes how their 3-month programme worked "From morning till night, speaking lessons, how to mop floors, clean windows, how to use washing machines in the Singapore condos, etc. Also, how to wash clothes, how to feed the children using milk bottles." 
Most importantly, they taught the women whom to approach in the event of a problem with the employer and reassure them that they were able to use their legal status to get help from the Singaporean government or Myanmar embassy.

"I told them to talk directly to the agent there (if in trouble) and I myself also phoned up their agent. Immediately, in their country if anything serious happens, they (Singapore RA) will go and fetch her back with the help of the police - They go and call back that person in a police car, with the siren wailing. After that, they bring her back to the agency and ask her whether she wants to go back and if not, they change her permit and move her to another house."

Recruitment agents recalled that a range of activities had been rendered illegal under the ban including advertising domestic work positions in Singapore and recruitment of female migrants for placement abroad. Highly publicised arrests of migration brokers and RAs appeared to be an effort to appease international pressures and show that serious steps were being taken to eliminate trafficking (interview, Federation of Recruitment Agencies). With experienced and respected brokers and RAs behind bars or not being allowed to trade, several unauthorised RAs emerged in Yangon to take advantage of the black market and rent-seeking opportunities as the demand for brokerage services continued (interview, Recruitment Agent A). These new agencies had neither a long history of social relations with their clients and nor were they regulated by the law. What was left was fly-by-night operators whose only control was through competition over placing workers in Singapore. Boosting the illegal business was an ever-permissive Singaporean state that turned a blind eye to recruitment practices in Myanmar.

\section{Impacts of criminalisation: rising costs, ill-prepared workers, extreme exploitation, extended debt repayment, no recourse to state support}

The ban had four major manifestations which I discuss in turn below: (1) a sharp increase in costs, (2) inadequate predeparture training and confinement of women prior to departure, (3) extended repayment periods and extremely exploitative and abusive conditions and (4) difficulties in accessing support from the Myanmar and Singapore governments.

\section{Inadequate predeparture training and confinement of women}

Under the ban, predeparture training became illegal (ILO and UN Women 2017). Our research shows that recruitment agencies that were operating illegally moved women and girls from one site to another to escape detection while waiting for their counterparts in Singapore to find an employer. Unauthorised agencies kept their operations well shielded from the law, and a common practice during the ban was for the recruitment agencies to hire a property in an informal settlement and use that as a training centre. These agencies moved address often to avoid being detected. According to Cynthia, who migrated twice, once in 2014 for 2 years and then again in 2016, the agency changed its address several times.

"Before I didn't understand, but later I came to understand that if anything happened to us, they didn't have a permanent address and we couldn't contact them. They live in Sanchaung for 3 months, 6 months and move to another place." 
The criminalisation of migration brokerage had an adverse impact on the personal freedom of women as well. Women attending predeparture training would be confined to escape detection and also to prevent them from going back home.

“They didn't allow us to go out all the time. If people saw that there were many girls, the authority will come and check them. If they knew that he was the agent, he would have to pay a fine. So, we were not allowed to go outside, only once a week in the evening to buy food."

"As far as I remember during these two months once we went to the pagoda and another time went to the market."

"They told the neighbours that their relatives from district came to attend school."

Often small flats would be crammed with 40-50 students. They would stay there for barely 2 months while they were given perfunctory lessons in English, cleaning, personal hygiene, daily routines and manners. In that time, the agents would link up with agents on the Singapore side who scouted for employers. According to the women we interviewed, inadequate predeparture training resulted in workers experiencing communication problems in Singapore, not being able to perform tasks expected of them, not understanding safety procedures or how to report problems to MOM should anything go wrong.

Cynthia who first migrated in 2014 was told only a day before her departure that she was to leave the next morning and was not allowed to speak to her parents.

"That time I didn't know. Only now when I think about it, they were not official agent and if they forced me they will be in trouble. So, I didn't see my family members the day that I left for the agent house and only after I came back from abroad I could see them."

The ban outlawed migration for domestic work as well as the training that was previously offered prior to departure. Our interviewees told us that predeparture training was critical for preparing the workers for Singapore's tough working conditions and differences in language, habits, household gadgets as well as food preparation. During the ban, predeparture training was either skipped altogether or compressed into a very short period and inadequate. One such case was 23-year-old Rita who is from Kachin and speaks no Myanmar or English migrated through an unauthorised agent in Yangon.

"My sister was learning Japanese in Yangon. Her teacher was sending people to foreign, and through her contact I went. The agent was Kachin and based in North Okkalapa. They didn't teach us anything. I stayed at the agent's house for 2-3 weeks. And then...I have to go. She didn't teach me anything and she gave me the book, Saw Thiha, the English-speaking book."

Another case was Htay Htay the daughter of a poor tenant farmer and educated only up to fourth standard. She migrated through an unauthorised RA in Yangon who procured a National Registration Certificate and passport and arranged for an interview with a prospective employer in Singapore in a short period of time. "After 3 weeks, they called me for interview. I couldn't even speak (English) well, but the boss called me... at that time, it was very quick." In Mona's case too, no predeparture training was offered in Myanmar.

Altogether, the experience of our interviewees suggests that varying degrees of training was offered. What is clear though is that the recruitment agencies were careful to protect their own interests. Several of the interviewees mentioned how, during their training before departure and after arrival, they were told by agents not to "jump out of a window" which indicates that 
the agents clearly knew they were placing them in such harsh working conditions that they are likely to contemplate suicide. If a worker did end their life, then the agents would stand to lose some of their earnings.

Those with the most basic training arrived in Singapore without a working knowledge of English or an understanding of the nature of the work. All but one said that they experienced problems in communicating with their employer. Furthermore, many of the women we interviewed had arrived in Singapore with unrealistic expectations. The exacting working conditions were a shock to many of them, but there was no escape as they were bound to the employer until they repaid the debt. Rudimentary training on the labour laws and cultural norms of Singapore was being offered by the MOEAF (Myanmar Overseas Employment Agencies Federation) from August 2014, but this did not contain information on the actual conditions of work such as long hours and rules with regard to food consumption, rest time and sleeping arrangements. ${ }^{9}$ Consequently, the dissatisfaction of employers and the turnover of Myanmar domestic workers was higher than other nationalities (HOME/MWRN 2015).

\section{Skyrocketing costs}

All the women in our sample who migrated during the ban were told by the village-level broker or the recruitment agent in Yangon that their wages would be deducted for 7-9 months which was longer than the preban debt repayment period. Hidden in these deductions were hefty fees for the brokers and recruitment agents which they justified on the grounds that travel would be more difficult to arrange, and bribes would have to be paid to officials to circumvent the ban. In a couple of cases, the worker was told that her debt had not been paid off even after 9 months.

Given wage rates between 450 and 550 Singapore dollars (roughly 331-404 USD), and deductions of 400-450 SGD (roughly 294-331 USD) per month, their total repayment was between roughly 2058-2646 and 2317-2979 USD. These repayment periods were longer than the 6-8 months, and total charges of 2300 SGD (about 1692 USD) reported in other studies during the ban (TWC2 2016; ILO 2017; HOME/MWRN 2015). This is despite the reiteration of the ILO Private Employment Agencies Convention, 1997 (No. 181) which states that "private employment agencies shall not charge, directly or indirectly, in whole or in part, any fees or costs to workers" (Article 7) as well as ILO tripartite stakeholder directives that "No recruitment fees or related costs should be charged to, or otherwise borne by, workers or jobseekers".

Four of the women interviewed mentioned that the recruiting agent in Yangon told them there would be further large payments if they suddenly changed their mind. This kind of behaviour on the part of the RAs was not common before the ban according to Cynthia who came to the agent's office where her parents were asked to sign a consent form and also a contract:

"They threatened us that we had to give 10, 15, 20 lakhs (1 lakh=100,000 MMK) if we didn't go. .. They asked for Household registration certificate and our parents had to

\footnotetext{
${ }^{9}$ The Straits Times, Myanmar government ban fails to stop maids heading to Singapore, by Amelia Tan, 29th September 2014. 
sign consent form. In the contract if we didn't go we had to pay 20 lakhs (1500 USD)

including the expenses for travelling with agent."

Mona was also made to sign a contract saying that if the migration did not work out, she would have to pay the agent 15 lakhs (about 1140 USD).

The Singapore government is not concerned with the recruitment fees paid in Myanmar and instead has set down rules that Singapore recruitment agencies should not charge more than 2 months of wages (900 SGD or 662 USD) which is much less than the amount they were being charged. The accounts show that this rule was frequently broken adding to the overall debt for the migrant. Wage deduction patterns varied a great deal with some brokers and employers deducting 5 months of wages as promised to the migrants before departure and others stretching the deductions for more than 9 months. Migrant accounts show that deductions were not transparent and arbitrary charges were imposed. Some were charged for undergoing tests and exams in Singapore, and this was added to the amount owed. Aung Nyein was told about monthly deductions to pay off the agent before she left in Myanmar. But her employer began to cut further amounts from her salary for the smallest things including postage stamps and telephone calls home. The employer also kept all the money that should have been paid to her as pocket money during the debt period leaving her with no money at all and no means of communicating with the outside world. There was a lack of clarity over the RAs, migrant's and employer's responsibility for certain costs such as redeployment costs.

\section{Forced labour conditions}

The extended payback periods of recruitment fees during the ban appear to have given employers extra control over their employees and carte blanche for extracting labour. There are guidelines in the Singaporean Employment of Foreign Manpower Act for the conditions in which foreign workers should be employed, but these are not legally mandated. Even though the guidelines state that female domestic workers should be given acceptable accommodation and adequate rest and food, these are not precise instructions and are open to interpretation by the employer and RA in Singapore. Employers can 'blacklist' a migrant worker by submitting a complaint to the Ministry of Manpower, which bans women workers from migrating to Singapore for up to 5 years (ILO and UN Women 2017). By all accounts, the treatment meted out to Myanmar domestic workers during the ban was much worse than before.

In Ma Lay's case, this took the form of asking her to work on chores beyond the assigned job; she was asked to do heavy-duty garden maintenance as well as work inside the house. She was not allowed to contact anyone beyond the employer's family for 7 months after arrival. She complained to the agent, but no action was taken and instead the agent threatened her with non-completion of the contract.

"I told the agent that I cannot do it. I am tired and the flowerpots are very heavy and I have to move them from place to place. I am tired and I suffered back pain."

"I continued working like that for 1 year and 3 months. The agent told me that as the agent fees did not settle yet, if I go I have to repay the money."

Controls on personal freedom, isolation, deprivation of food and rest also appeared to reach extreme levels. Although it was common practice for employers to withhold 
passports and identity documents to prevent workers running away, our interviewees said that working conditions during the ban were worse than they were before based on their discussions with other returning migrants. Thet Win migrated in 2015 through what she thought was an officially registered agent as she found a pamphlet in Yangon explaining the process. In her employer's home, she had very little control over her body and living conditions. She was forced to sleep in the children's room and was allowed to enter only after the boss had put them to bed. She was allowed only half an hour a month to speak to her daughter, restricted on the amount she could eat and allowed to wash only late at night.

"From 10 PM after I finished my work, I couldn't go to sleep, I have to wait until the child is asleep. ..They let me use (phone) only once a month for half an hour to have phone contact with my family. I told her to give me extra time, but she didn't. And also for the food, for breakfast she gave me only 2 slices of bread and a cup of Milo. I was not allowed to eat more." I told her that the previous house gave me 3 slices of bread. She said why should I eat more?

"They also make restriction that in not included in the contract. Sometimes I finished my housework at 10-11 PM and I have to take shower only at 11 PM.. If I ask, she told me that she did according to the contract."

\section{No protection from Myanmar government}

Migration without official approvals in Myanmar carried the risk of not having government support in Singapore. Most of the women in our sample had migrated on tourist visas, and although they would have work permits in Singapore, that did not entitle them to support from the Myanmar government in the event of a problem arising at work. Nearly all of them said that their placement agents in Singapore were reluctant to help if there was a problem and in half the cases the agent was abusive in their tone, shouting at the workers if they complained about being overworked or worked beyond the terms of their contract. One woman says her agent confiscated the information handed to the migrant after arrival by MOM and ripped up the papers and phone numbers in front of her. MOM officials were more responsive if the complaint reached them but in most cases it did not as the agent would try to contain the problem either by threatening the worker with more charges or moving them to another employer. One of the women said that even though her complaint did reach MOM, one of the officers there told her to have patience and try harder.

What these experiences show is that women who migrated during the ban had few sources of support. Confined in hidden spaces in a foreign country that they do not understand how to navigate, and with limited routes to have their complaints heard, it took extreme will power to stay with abusive employers. In our sample, there was one woman who tried several times to find a better job, but when the agent continued to blame her for being 'lazy' and 'good for nothing', ran away and was eventually repatriated by MOM. Others said that employers threatened to have them blacklisted and sent home, denying them the opportunity to start earning after the loan repayment. Two of the women were falsely blacklisted by their employers for resisting harsh treatment, but they had no mechanism to challenge the accusation in a system that was geared to protecting employers and condoning unscrupulous practices of agents. 


\section{Analysis and conclusion}

Myanmar has now become an important country of origin for migrant domestic workers in affluent countries in Southeast Asia due to the limited opportunities for gainful employment for women within the country. Singapore is an important destination because of the relatively high wages offered, and it continues to attract large numbers of women from disadvantaged backgrounds who aspire to improve their family's standard of living. A significant proportion of the women interviewed were divorced or separated indicating that this kind of migration is an important source of income for women without a male provider to support them.

Myanmar has historically taken a paternalistic approach to the migration of women due to a moralizing discourse which regards them as vulnerable to exploitation and in need of state protection. But women were migrating regardless, and for a short period of time, their migration was state sanctioned with officially registered recruitment agencies in urban areas recruiting them and placing them in Singapore homes. However, reports of abuse of such migrant women from NGOs led to a ban being imposed, and the evidence presented in this paper has shown how the ban, together with Singapore's indifference to the way in which workers were recruited, resulted in extreme hardship and exploitation.

The ban on migration for domestic work to Singapore and criminalisation of migration brokerage in Myanmar disrupted established systems based on bonds of trust that were part of a larger system of patronage in rural areas. It resulted in the mushrooming of numerous clandestine and unscrupulous operators that took advantage of emerging opportunities in the black market. Migrants were left at the mercy of a new kind of unscrupulous recruitment and placement agent who was bound by neither moral rules nor laws. These new RAs imposed higher than usual fees and charges on workers and placed them in forced labour conditions with few sources of support. Due to inadequate predeparture training, Myanmar migrants were poorly informed about the actual working conditions in Singapore and poorly trained in language and domestic tasks.

Singapore's model of worker recruitment and immigration heavily circumscribes the rights of migrant labour through the regulation of their residence and reproductive rights. The focus of the policy is to ensure that workers are physically fit and not pregnant. Their working conditions are left to the discretion of employers, and there are no enforced regulations on working hours, the provision of food to the worker, days off or being able to communicate with their peers and family back home. That such an arrangement creates scope for exploitation was already noted by academics and NGOs working to protect the rights of migrant women. The interviews presented here show that levels of exploitation were extreme during the ban due to extended loan repayment periods and the inability of workers to seek help from either government. As such, the ban combined with Singapore's migration management regime and lack of political commitment to protecting migrants ${ }^{10}$ had created a situation of extreme dependency and powerlessness among migrant women who were vulnerable to extreme exploitation. As most women who migrated to Singapore during the ban had travelled on tourist visas, they were unable to seek protection from the Myanmar government as workers.

Our interviews indicated that among our respondents and their networks, most cases of domestic work in Singapore prior to the ban did not involve extreme abuse and exploitation. Migrants viewed brokers as patrons who helped them to escape poverty traps but in contrast, the policy discourse focused on extreme cases to justify the ban. By characterizing brokers as evil criminals the responsibility for migrant precarity and suffering was deflected away from restrictive state policies.

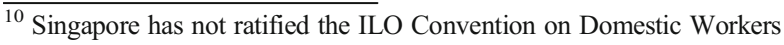


The research has shown the indifference of the Singapore government towards the manner in which domestic workers are recruited and supplied added to their precarity and exacerbated the effects of the ban. According to HOME and other rights groups working in Singapore, the authorities consistently turn a blind eye to bad working conditions and long debt repayment periods where workers go without pay. The use of extreme control strategies such as food and rest deprivation as well as constant surveillance was routine during the ban. Employers also tried to extend the loan repayment period through arbitrary deductions and charges and were able to do so as there were no real checks on their practices from either government.

It is imperative for the government of Myanmar to create a more supportive environment for those who wish to migrate. It is working closely with the ILO to introduce a code of practice for recruitment agencies after removing the ban on migration for domestic work. However, creating a layer of official agencies that continue to be heavily regulated will not solve the problems it seeks to address. The government should rethink its approach to migration brokerage and rather than positioning the state as the only legitimate facilitator, it should encourage migrants to build on community systems of brokerage but with a stronger and more accessible guiding hand to help migrants understand formal procedures and reduce opportunities for rent-seeking.

Additionally, the government of Myanmar should continue bilateral negotiations with Singapore to step up measures to protect migrant domestic workers' rights by monitoring the entire supply chain from recruitment to placement. The Singapore government should be urged to take more responsibility for the terms under which workers are employed, including their overall debt and repayment conditions. At the same time NGOs such as HOME and TWC2 (Transient Workers Count Too) should continue to draw attention to the weak political commitment of the Singaporean government towards creating decent work conditions for migrant domestic workers. They should increase efforts to create more public awareness on the issue and demand punishment for abusive employers.

Funding The research on which this paper is based was funded by the UK Government's Department for International Development/UK Aid under the British Academy project 'Brokered migration for domestic work and construction work in Ghana and Myanmar: examining the relevance of the slavery and trafficking discourse'.

Open Access This article is licensed under a Creative Commons Attribution 4.0 International License, which permits use, sharing, adaptation, distribution and reproduction in any medium or format, as long as you give appropriate credit to the original author(s) and the source, provide a link to the Creative Commons licence, and indicate if changes were made. The images or other third party material in this article are included in the article's Creative Commons licence, unless indicated otherwise in a credit line to the material. If material is not included in the article's Creative Commons licence and your intended use is not permitted by statutory regulation or exceeds the permitted use, you will need to obtain permission directly from the copyright holder. To view a copy of this licence, visit http://creativecommons.org/licenses/by/4.0/.

\section{References}

Alpes, M. J. (2013). Law and the credibility of migration brokers. Working Paper 80. International Migration Institute, University of Oxford.

Awumbila, M., Deshingkar, P., Kandilige, L., Teye, J. K., \& Setrana, M. (2019). Please, thank you and sorrybrokering migration and constructing identities for domestic work in Ghana. Journal of Ethnic and Migration Studies, 45(14), 2655-2671.

Baey, G., \& Yeoh, B. S. (2018). "The lottery of my life": migration trajectories and the production of precarity among Bangladeshi migrant workers in Singapore's construction industry. Asian and Pacific Migration Journal, 27(3), 249-272. 
CEDAW (2016). Concluding observations on the combined fourth and fifth periodic reports of Myanmar. Committee on the elimination of discrimination against women. (CEDAW/C/MMR/CO/4-5).

Chin, C. (2019). Precarious work and its complicit network: migrant labour in Singapore. Journal of Contemporary Asia published online 16 February 2019.

Deshingkar, P., Abrar, C. R., Sultana, M. T., Haque, K. N. H., \& Reza, M. S. (2019). Producing ideal Bangladeshi migrants for precarious construction work in Qatar. Journal of Ethnic and Migration Studies, 45(14), 2723-2738.

Fong, E., \& Yeoh, B. S. (2020). Migrant domestic workers: disadvantaged work, social support, and collective strategies in East Asia. American Behavioral Scientist, 64(6), 703-708.

Fong, E., Shibuya, K., \& Chen, X. (2020). Migration among east and southeast Asian economies. International Migration, 58(4), 69-84.

Goh, C., Wee, K., \& Yeoh, B. S. A. (2017). Migration governance and the migration industry in Asia: moving domestic workers from Indonesia to Singapore. International Relations of the Asia-Pacific., 17(3), 401-433.

Goldring, L., Berinstein, C., \& Bernhard, J. K. (2009). Institutionalizing precarious migratory status in Canada. Citizenship Studies, 13(3), 239-265.

HOME. (2019). Behind closed doors: forced labour in the domestic work sector in Singapore. Singapore: Humanitarian Organization for Migration Economics \& Liberty Shared.

HOME/MWRN. (2015). Submission for the 23rd session of the universal periodic review, United Nations human rights, Office of the High Commissioner. November 2015. Humanitarian Organization for Migration Economics and Migrant Worker Rights Network.

ILO. (2017). Global estimates of modern slavery. Geneva: International Labour Organization. https://www.ilo. org/wcmsp5/groups/public/\%2D\%2D-dgreports/\%2D\%2D-dcomm/documents/publication/wcms_575479. pdf. Accessed on 4 Dec 2019.

ILO and UN Women. (2017). Protected or put in harm's way? Bans and restrictions on women's labour migration in ASEAN countries. Bangkok: International Labour Organization and UN Women.

IOM. (2019). Myanmar in motion: from human trafficking to regular migration. Yangon: IOM Myanmar. Accessed on 4 Dec 2019.

Lindquist, J. (2012). The elementary school teacher, the thug and his grandmother: informal brokers and transnational migration from Indonesia. Pacific Affairs, 85(1), 69-89.

$\mathrm{Ma}$, A. (2019). Labour migration, remittances and development in the Myanmar-Singapore corridor. PhD thesis, University College London.

MOLIP/UNWomen. (2017). Study on the impact of protective policies for Myanmar migrant domestic workers in Thailand and Singapore. Ministry of Labour, Immigration and Population, Myanmar/UNWomen.

Okyere, S. (2017). 'Shock and awe': a critique of the Ghana-centric child trafficking discourse. Anti-Trafficking Review, 2017(9), 92-105.

Osella, F. (2014). The (im) morality of mediation and patronage in South India and the Gulf. In Patronage as politics in South Asia (pp 365-394). New Delhi: Cambridge University Press.

Parreñas, R. S., Kantachote, K., \& Silvey, R. (2020). Soft violence: migrant domestic worker precarity and the management of unfree labour in Singapore. Journal of Ethnic and Migration Studies, published online 2 April. https://doi.org/10.1080/1369183X.2020.1732614.

Platt, M. (2018). Migration, moralities and moratoriums: female labour migrants and the tensions of protectionism in Indonesia. Asian Studies Review, 42(1), 89-106.

Platt, M., Yeoh, B. S., Baey, G., Khoo, C. Y., Lam, T., Das, D., \& Ee, M. (2013). Financing migration, generating remittances and the building of livelihood strategies: a case study of Indonesian migrant women as domestic workers in Singapore. Working paper, 10. Migrating Out of Poverty Research Programme Consortium, University of Sussex.

Platt, M., Baey, G., Yeoh, B. S. A., Khoo, C. Y., \& Lam, T. (2017). Debt, Precarity and gender: male and female temporary labour migrants in Singapore. Journal of Ethnic and Migration Studies, 43(1), 119-136.

Provine, D. M., \& Doty, R. (2011). The criminalization of immigrants as a racial project. Journal of Contemporary Criminal Justice, 27(3), 261-277.

Spener, D. (2009). Some critical reflections on the migration industry concept. Paper presented at workshop on Migration in the Pacific Rim, University of California, Los Angeles.

Van Liempt, I., \& Sersli, S. (2013). State responses and migrant experiences with human smuggling: a reality check. Antipode, 45(4), 1029-1046.

Wee, K., Goh, C., \& Yeoh, B. S. A. (2019). Chutes-and-ladders: the migration industry, conditionality, and the production of precarity among migrant domestic workers in Singapore. Journal of Ethnic and Migration Studies, 45(14), 2672-2688.

Wei, A. C. (2015). Myanmar slaps fresh ban on maids for Singapore. Straits Times. https://www.straitstimes. com/singapore/myanmar-slaps-fresh-ban-on-maids-for-singapore. Accessed 16 Apr 2019.

Publisher's Note Springer Nature remains neutral with regard to jurisdictional claims in published maps and institutional affiliations. 